\title{
Combined Effect of Thermoplastic and Thermosetting Adhesives on Properties of Particleboard With Rice Husk Core
}

\author{
Jin Heon Kwon ${ }^{a *}$, Nadir Ayrilmis ${ }^{b}$, Tae Hyung Han ${ }^{a}$ \\ ${ }^{a}$ Department of Forest Biomaterials Engineering, College of Forest and Environmental Sciences, \\ Kangwon National University, 200-701 Chuncheon city, Republic of Korea \\ ${ }^{b}$ Department of Wood Mechanics and Technology, Forestry Faculty, Istanbul University, Bahcekoy, \\ Sariyer, 34473, Istanbul, Turkey
}

Received: April 2, 2014; Revised: August 19, 2014

\begin{abstract}
This study investigated the combined effect of adhesive type and content on the dimensional stability and mechanical properties of three-layer particleboards made from a mixture of wood particles (face layer: $30 \mathrm{wt} \%$ ) and rice husk particles (core layer: $70 \mathrm{wt} \%$ ). Two types of thermosetting adhesives, liquid urea-formaldehyde (UF) and phenol-formaldehyde (PF), and thermoplastic adhesive (low density polyethylene: LDPE) powder were used as binder in the experiments. Thickness swelling and water absorption of the particleboards significantly decreased with increasing content of the LDPE powder. The incorporation of LDPE powder into the core layer of particleboard greatly improved the internal bond strength.
\end{abstract}

Keywords: dimensional stability, mechanical properties, phenol formaldehyde, urea-formaldehyde, thermoplastic adhesive, particleboard, rice husk

\section{Introduction}

The rate of global deforestation and its impact on the environment has led particleboard manufacturers to search for alternative feedstock, especially in countries where wood is less available compared to other cellulosic natural products. The use of renewable resources such as agricultural residues, is gaining increased interest in production of particleboard. Rice husks are important byproduct of the rice milling process, which are available in fairly large quantities in certian agricultural areas. It is reported that about 0.23 tons of the rice husk are generated per ton of rice produced ${ }^{1}$. The main components of rice husk are cellulose ( 25 to $35 \%$ ), hemicellulose (18 to $21 \%$ ), lignin (26 to $31 \%$ ), silica (15 to $17 \%$ ), solubles (2 to $5 \%$ ), and moisture content of $5-10 \%{ }^{2}$. The reasons behind the use of rice husk in particleboard industry are its high availability, low bulk density $\left(90-150 \mathrm{~kg} / \mathrm{m}^{3}\right)$, toughness, abrasive in nature, resistance to weathering and unique composition $^{3}$. Although previous studies reported that rice husk particleboard could be used in the manufcture of furniture and interior fitments, the physical and mechanical properties of the particeboards were lower than those of the particleboards made from wood particles ${ }^{4-6}$. The main reasons for lower physical and mechanical properties of the rice husk particleboards are low aspect ratio and waxy/silica layer of the rice husk particles.

Polyethylene adhesives are milky white, translucent substances derived from ethylene $\left(\mathrm{CH}_{29} \mathrm{CH}_{2}\right)$. Low density polyethylene (LDPE) typically has long side-chain branching off the main molecular chain and therefore is a more amorphous polymer those branched polyethylene

*e-mail : kwon@kangwon.ac.kr plastics, having a standard density of $0.91-0.92 \mathrm{~g} / \mathrm{cm}^{3}$. LDPE is the most widely used of all plastics, because it is inexpensive, chemical-resistant, very resistant to fungal attack, and have good dimensional stability when exposed to moisture ${ }^{7}$. Instead of urea-formaldehyde (UF) adhesive, LDPE offers many environmental and technological benefits when used as a binder for wood particles in the core layer of rice husk particleboard, such as no formaldehyde emission, higher water and fungal resistance.

The UF adhesive is one of the most common adhesives used in wood-based panel industry. Its low price and good strength properties of glue lines under dry conditions result in its being widely applied despite its low water resistance $^{8}$. In order to increase water resistance of UF adhesives, they are commonly modified with melamine ${ }^{9}$ and diisocyanate ${ }^{10}$. Investigations conducted in this respect showed that the application of melamine and isocyanates in the UF adhesive improved the glue-line strength to a considerable degree and increased water resistance of the UF adhesive ${ }^{9,10}$. However, modifiers are still expensive and increase the cost of UF adhesive. Polyethylene matrix is extensively used in the production of lignocellulosic filled thermoplastic composites because it is high performance binder for lignocellulosics ${ }^{11-13}$. For this reason, LDPE could play an important role in the production of particleboard having a rice husk core.

When a particeboard is used in moist areas, it absorbs water. The core layer of particleboard is mainly responsible for thickness swelling (TS) and water absorption (WA) due to its high shell ratio. If the voids and spaces among the rice husk particles are filled by the melted LDPE, the dimensional 
stability of the particleboard can be improved. Internal bond strength of the particleboard having a rice husk core can be improved as the rice husk particles are encapsulated in the hydrophobic LDPE matrix. The objective of this study was to investigate the combined effect of liquid thermosetting adhesives (UF or phenol-formaldehyde (PF) adhesives) and powder thermoplastic adhesive (LDPE) on the dimensional stability and mechanical properties of three-layer particleboard. The particleboards were made from a mixture of rice husk particles (core layer: $70 \mathrm{wt} \%$ ) and wood particles (face layer: $30 \mathrm{wt} \%$ ). The wood particles used in the top and bottom layers were bonded with UF or $\mathrm{PF}$ adhesive while the core layer consisting of rice husk particles were bonded with a mixture of the thermosetting adhesives (UF or PF adhesive) and LDPE powder.

\section{Experimental}

\subsection{Materials}

The rice husk particles were obtained from a rice mill in Chuncheon, capital city of Gangwon Province, South Korea. The average moisture content of rice husk particles prior to the production of the particleboards was $5 \%$ based on the oven-dry weight of the rice husk particles. The average length, width, and thickness of rice husk particles used in the experiments were $6.79 \pm 0.35 \mathrm{~mm}, 2.96 \pm 0.26 \mathrm{~mm}$, $0.17 \pm 0.02 \mathrm{~mm}$, respectively (these values were an average of 30 the rice husks and standard deviation). The wood particles having a moisture content of $4-5 \%$ were obtained from a commercial particleboard company located in South Korea. The average length, width, and thickness of wood particles were $13.53 \pm 3.72 \mathrm{~mm}, 1.95 \pm 0.74 \mathrm{~mm}, 0.97 \pm 0.40 \mathrm{~mm}$, respectively.

A commercial E1 (urea/formaldehyde ratio: 1/0.8, viscosity: $180 \mathrm{cps}$ ) grade liquid UF adhesive with a solid content of $56 \mathrm{wt} \%$ and liquid PF adhesive (viscosity: $195 \mathrm{cps}$ ) with a solid content of $59.4 \%$ were used in the production of the particleboards. The UF and PF adhesives were supplied by Hansolhomedeco company in Iksan city, South Korea. As a hardener $1 \%$ of ammonium chloride $\left(\mathrm{NH}_{4} \mathrm{Cl}\right)$ solution with $20 \mathrm{wt} \%$ solids content based on the UF adhesive solids content was added in to the UF adhesive solution. This study did not include the addition of any external wax or water-repellent chemicals to the wood and rice husk particles.

The LDPE powder (particle size: 50 mesh, melting temperature $=105{ }^{\circ} \mathrm{C}$, density $=0.926 \mathrm{~g} / \mathrm{cm}^{3}$, MFI (melt flow index) $=24 \mathrm{~g} / 10 \mathrm{~min}$ ) was supplied by M.J Powder company in Ulsan city, South Korea.

\subsection{Production of experimental particleboards}

Three-layer particleboards consisting of a central layer (core) and two outer layers (faces) were manufactured under laboratory conditions (Figure 1). Both surfaces were made from the fine wood particles while the core layer was made from rice husk particles. The surface and core particles were separately placed in a drum blender. Then the UF adhesive was applied with an air-atomized metered spray system for 5 min to obtain a homogenized mixture. This procedure was also performed for the PF adhesive application. The LDPE powder was applied to the core particles with UF adhesive or PF adhesive. In the first phase, six levels of the LDPE powder (5-30 wt \%) based on the composition by weight, were mixed with the core particles (rice husk) with $8 \mathrm{wt} \%$ UF adhesive. In the second phase, the LDPE powder content was kept constant at $10 \mathrm{wt} \%$ in all the treatments and the UF adhesive or PF adhesive contents applied to the core layer was decreased gradually from 8 to $4 \mathrm{wt} \%$. The experimental design was presented in Table 1.

The layer construction of the particleboards based on the oven-dried weight ratio of the wood particles was 15:70:15 (face/core/face). The surface and core particles for three-layer boards were separately weighed and distributed evenly by hand into a $400 \mathrm{~mm}$ x $400 \mathrm{~mm}$ forming box. Release agent was used to avoid direct contact of the wood particles with the steel caul plates during heating and pressing. To reduce the mat height and to densify the mats, they were subjected to a cold-press. Particleboard mats having $10 \%$ moisture content were subjected to hot-press, using a manually controlled, electrically heated press. The hot press temperature, maximum pressure, and total press cycle were $180{ }^{\circ} \mathrm{C}, 2.5 \mathrm{~N} / \mathrm{mm}^{2}$, and $5 \mathrm{~min}$, respectively. The particleboards were then trimmed to a final size of $380 \mathrm{~mm} \times 380 \mathrm{~mm} \times 10 \mathrm{~mm}$ after the cooling process. A total of 72 particleboards, three for each type of formulation and control, were produced (Table 1). The average density values of the particleboards varied from 805 to $825 \mathrm{~kg} / \mathrm{m}^{3}$.

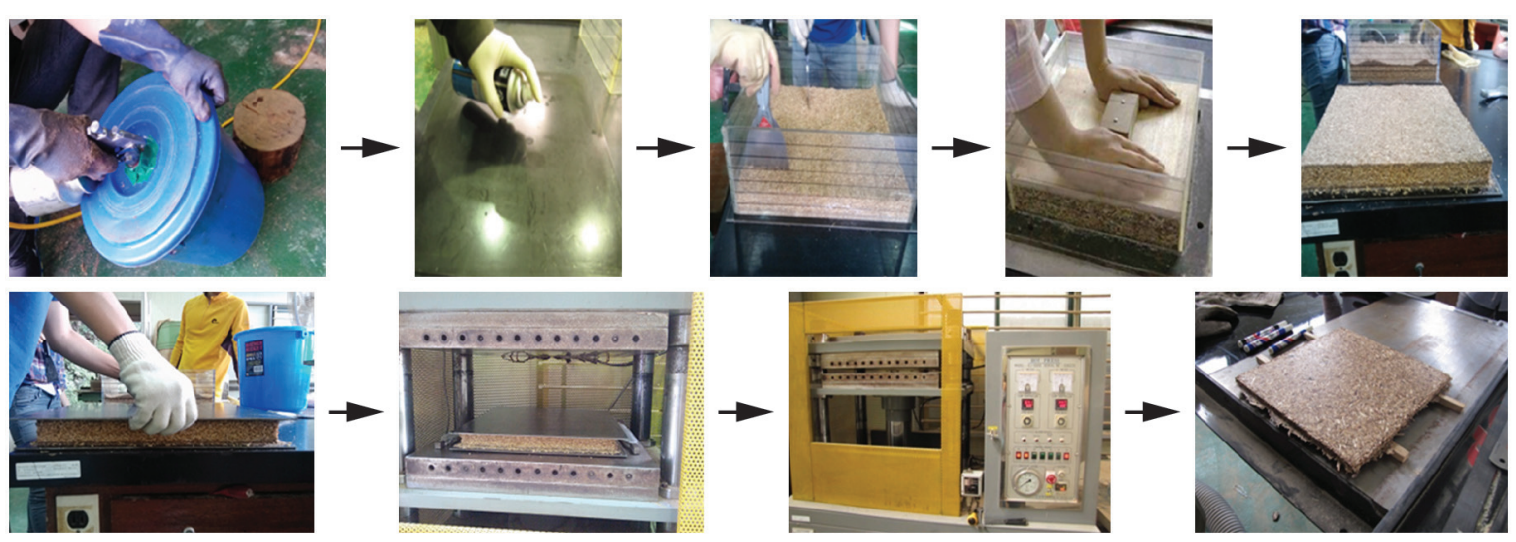

Figure 1. Laboratory-scale production of three-layer particleboards. 
Table 1. Experimental design.

\begin{tabular}{|c|c|c|c|c|c|c|c|c|}
\hline \multirow{3}{*}{$\begin{array}{l}\text { Particleboard } \\
\text { type }\end{array}$} & \multicolumn{8}{|c|}{ Particleboard composition } \\
\hline & \multicolumn{2}{|c|}{$\begin{array}{l}\text { Layer composition } \\
\text { (\% weight) }\end{array}$} & \multicolumn{2}{|c|}{$\begin{array}{c}\mathrm{UF}^{1} \text { adhesive content } \\
\text { (\% weight) }\end{array}$} & \multicolumn{2}{|c|}{$\begin{array}{c}\mathrm{PF}^{2} \text { adhesive content } \\
\text { (\% weight) }\end{array}$} & \multicolumn{2}{|c|}{$\begin{array}{l}\text { LDPE }^{3} \text { powder content } \\
\text { (\% weight) }\end{array}$} \\
\hline & $\begin{array}{c}\text { Surface } \\
\text { layer: wood }\end{array}$ & $\begin{array}{l}\text { Core layer: } \\
\text { Rice husk }\end{array}$ & Surface & Core & Surface & Core & Surface & Core \\
\hline $\mathrm{A}$ & 30 & 70 & 12 & 8 & - & - & - & - \\
\hline $\mathrm{B}$ & 30 & 65 & 12 & 8 & - & - & - & 5 \\
\hline $\mathrm{C}$ & 30 & 60 & 12 & 8 & - & - & - & 10 \\
\hline $\mathrm{D}$ & 30 & 55 & 12 & 8 & - & - & - & 15 \\
\hline $\mathrm{E}$ & 30 & 50 & 12 & 8 & - & - & - & 20 \\
\hline $\mathrm{F}$ & 30 & 45 & 12 & 8 & - & - & - & 25 \\
\hline G & 30 & 40 & 12 & 8 & - & - & - & 30 \\
\hline $\mathrm{H}$ & 30 & 70 & - & - & 12 & 8 & - & - \\
\hline I & 30 & 65 & - & - & 12 & 8 & - & 5 \\
\hline $\mathrm{J}$ & 30 & 60 & - & - & 12 & 8 & - & 10 \\
\hline $\mathrm{K}$ & 30 & 55 & - & - & 12 & 8 & - & 15 \\
\hline $\mathrm{L}$ & 30 & 50 & - & - & 12 & 8 & - & 20 \\
\hline M & 30 & 45 & - & - & 12 & 8 & - & 25 \\
\hline $\mathrm{N}$ & 30 & 40 & - & - & 12 & 8 & - & 30 \\
\hline $\mathrm{C}$ & 30 & 60 & 12 & 8 & - & - & - & 10 \\
\hline $\mathrm{O}$ & 30 & 60 & 12 & 7 & - & - & - & 10 \\
\hline $\mathrm{P}$ & 30 & 60 & 12 & 6 & - & - & - & 10 \\
\hline $\mathrm{R}$ & 30 & 60 & 12 & 5 & - & - & - & 10 \\
\hline $\mathrm{S}$ & 30 & 60 & 12 & 4 & - & - & - & 10 \\
\hline $\mathrm{J}$ & 30 & 60 & - & - & 12 & 8 & - & 10 \\
\hline $\mathrm{T}$ & 30 & 60 & - & - & 12 & 7 & - & 10 \\
\hline $\mathrm{U}$ & 30 & 60 & - & - & 12 & 6 & - & 10 \\
\hline $\mathrm{V}$ & 30 & 60 & - & - & 12 & 5 & - & 10 \\
\hline W & 30 & 60 & - & - & 12 & 4 & - & 10 \\
\hline
\end{tabular}

${ }^{1}$ UF: urea-formaldehyde. ${ }^{2} \mathrm{PF}$ : phenol-formaldehyde. ${ }^{3} \mathrm{LDPE}$ : Low density polyethylene.

Prior to the physical and mechanical tests all the specimens prepared from the particleboard the specimens were conditioned in a climatized room at $20^{\circ} \mathrm{C}$ and $65 \%$ relative humidity. Duration of the conditioning process was determined by regular weighing of the specimens until no changes in the weights were detected.

\subsection{Determination of dimensional stability}

The TS and WA tests were carried out according to EN 317 (1993). Ten replicate specimens, $50 \mathrm{~mm}$ x $50 \mathrm{~mm}$ x 10 $\mathrm{mm}$, from each type of particleboard were used for the TS and WA properties. At the end of 1-day of submersion, the specimens were taken out from the water and all surface water was removed with a clean dry cloth. The specimens were weighed to the nearest $0.01 \mathrm{~g}$ and measured to the nearest $0.001 \mathrm{~mm}$ immediately. The specimen thickness was determined by taking a measurement at a specific location, the diagonal crosspoint, on the specimen. The densities of specimens were evaluated according to the test method specified in EN 323 (1993).

\subsection{Determination of mechanical properties}

The bending strength (MOR) and modulus of elasticity (MOE) of the specimens were performed according to EN 310 (1993). A total of nine replicate specimens with dimensions of $250 \mathrm{~mm} \times 50 \mathrm{~mm} \times 10 \mathrm{~mm}$ were tested for each type of particleboard. The bending tests were conducted in accordance with the third point loading method at a spanto-depth ratio of $20: 1$. The crosshead speed was adjusted so that the failure would occur within an average of $60 \mathrm{~s} \pm 10$. The specimens were tested on Instron testing machine (Model: 4482) equipped with a load cell with a capacity of $10 \mathrm{kN}$. The internal bond (IB) strength tests were conducted on the specimens cut from the particleboards according to EN 319 (1993). Ten replicate specimens with dimensions of $50 \mathrm{~mm} \times 50 \mathrm{~mm} \times 10 \mathrm{~mm}$ from each type of paricleboard were used to determine the IB strength.

\subsection{Statistical analysis}

An analysis of variance, ANOVA, was conducted ( $\mathrm{p}<$ 0.01 ) to evaluate the effect of adhesive type and adhesive/ LDPE content on the physical and mechanical properties of the particleboards. Significant differences between the average values of types of the particleboards were determined using Duncan's multiple range test.

\section{Results and discussion}

\subsection{Dimensional stability}

The TS and WA values of the particleboards are presented in Table 2. The dimensional stability of the specimens was greatly improved by increasing the LDPE 
Table 2. Physical and mechanical properties of the particleboards.

\begin{tabular}{|c|c|c|c|c|c|c|}
\hline \multirow[b]{2}{*}{$\begin{array}{c}\text { Particleboard } \\
\text { type }^{1}\end{array}$} & \multicolumn{3}{|c|}{ Physical properties } & \multicolumn{3}{|c|}{ Mechanical properties } \\
\hline & $\begin{array}{l}\text { Density } \\
\left(\mathrm{g} / \mathrm{cm}^{3}\right)\end{array}$ & $\begin{array}{c}\text { Thickness } \\
\text { swelling } \\
(\%)\end{array}$ & $\begin{array}{c}\text { Water } \\
\text { absorption } \\
(\%)\end{array}$ & $\begin{array}{c}\text { Modulus } \\
\text { of rupture } \\
\text { (MPa) }\end{array}$ & $\begin{array}{c}\text { Modulus of } \\
\text { elasticity } \\
\text { (GPa) }\end{array}$ & $\begin{array}{l}\text { Internal bond } \\
\text { strength } \\
\text { (MPa) }\end{array}$ \\
\hline A & $820(10)$ & $102.9(4.2) \mathrm{a}^{2}$ & $95.5(3.7) \mathrm{a}$ & $10.9(0.8) \mathrm{a}$ & $2.13(0.10) \mathrm{a}$ & $0.03(0.005) \mathrm{a}$ \\
\hline B & $811(17)$ & $58.6(2.5) \mathrm{b}$ & $85.9(3.1) b$ & $11.2(0.7) \mathrm{ab}$ & $2.20(0.08) \mathrm{ab}$ & $0.04(0.005)$ af \\
\hline $\mathrm{C}$ & $823(12)$ & $42.4(2.2) \mathrm{c}$ & $68.9(2.7) \mathrm{c}$ & $12.1(0.9) b c$ & $2.27(0.10) \mathrm{ab}$ & $0.07(0.007) \mathrm{bj}$ \\
\hline $\mathrm{D}$ & $806(18)$ & $33.6(2.3) \mathrm{d}$ & $62.28(2.4) \mathrm{d}$ & $12.9(1.0) \mathrm{bcd}$ & $2.35(0.08) b c$ & $0.09(0.006) b c$ \\
\hline $\mathrm{E}$ & $820(20)$ & $25.1(1.9) \mathrm{e}$ & $56.0(1.7) \mathrm{em}$ & $13.3(0.8)$ cde & $2.42(0.05) \mathrm{cd}$ & $0.10(0.005) \mathrm{cg}$ \\
\hline $\mathrm{F}$ & $810(21)$ & $16.1(1.4) \mathrm{f}$ & $45.7(2.0) \mathrm{fl}$ & $14.3(0.9)$ def & $2.50(0.06) \mathrm{cd}$ & $0.12(0.08) \mathrm{dg}$ \\
\hline G & $805(25)$ & $13.2(1.2) \mathrm{g}$ & $39.2(1.5) \mathrm{g}$ & $14.6(1.1) \mathrm{def}$ & $2.51(0.10) \mathrm{cd}$ & $0.14(0.007)$ ehd \\
\hline $\mathrm{H}$ & $824(24)$ & $32.2(1.3) \mathrm{d}$ & $70.1(2.6) \mathrm{cj}$ & $13.6(1.1) \mathrm{cde}$ & $2.22(0.09) \mathrm{ab}$ & $0.05(0.004) \mathrm{fi}$ \\
\hline I & $821(18)$ & $25.8(1.5) \mathrm{e}$ & $57.8(2.3) \mathrm{e}$ & $14.4(0.9) \mathrm{def}$ & $2.35(0.010) b c$ & $0.05(0.006) \mathrm{fi}$ \\
\hline $\mathrm{J}$ & $808(20)$ & $16.3(0.8) \mathrm{f}$ & $42.8(2.5) \mathrm{f}$ & $15.2(1.0) \mathrm{fg}$ & $2.42(0.011) \mathrm{cd}$ & $0.09(0.008) \mathrm{cg}$ \\
\hline $\mathrm{K}$ & $818(15)$ & $13.2(0.6) \mathrm{g}$ & $36.9(1.7) \mathrm{g}$ & $15.6(1.1) \mathrm{fg}$ & $2.49(0.011) \mathrm{cd}$ & $0.11(0.009) \mathrm{cg}$ \\
\hline $\mathrm{L}$ & $812(23)$ & $10.9(0.6) \mathrm{h}$ & $27.3(2.0) \mathrm{h}$ & $16.2(1.3) \mathrm{gh}$ & $2.58(0.011) \mathrm{d}$ & $0.13(0.009) \mathrm{dh}$ \\
\hline M & $808(15)$ & $7.2(0.4) \mathrm{i}$ & $21.3(1.5) \mathrm{i}$ & $16.9(1.2) \mathrm{gh}$ & $2.61(0.09) \mathrm{d}$ & $0.15(0.01) \mathrm{h}$ \\
\hline $\mathrm{N}$ & $822(22)$ & $6.3(0.5) \mathrm{i}$ & $20.8(1.8) \mathrm{i}$ & $17.4(1.4) \mathrm{h}$ & $2.63(0.012) d$ & $0.19(0.01) \mathrm{k}$ \\
\hline $\mathrm{C}$ & $823(12)$ & $42.4(2.2) \mathrm{c}$ & $68.9(2.7) \mathrm{c}$ & $12.1(0.9) \mathrm{bc}$ & $2.27(109) \mathrm{ab}$ & $0.07(0.007) \mathrm{bj}$ \\
\hline $\mathrm{O}$ & $818(16)$ & $42.9(1.9) \mathrm{c}$ & $69.6(1.8) \mathrm{c}$ & $11.9(1.0) \mathrm{ab}$ & $2.20(113) \mathrm{a}$ & $0.06(0.006) \mathrm{ji}$ \\
\hline $\mathrm{P}$ & $821(21)$ & $43.8(2.4) \mathrm{c}$ & $73.6(2.8) \mathrm{j}$ & $11.2(0.9) \mathrm{ab}$ & $2.15(0.01) \mathrm{ab}$ & $0.05(0.007) \mathrm{fi}$ \\
\hline $\mathrm{R}$ & 815 (18) & $44.6(2.1) \mathrm{c}$ & $73.7(3.2) \mathrm{j}$ & $11.0(1.1) \mathrm{ab}$ & $2.09(0.09) \mathrm{a}$ & $0.04(0.004)$ af \\
\hline $\mathrm{S}$ & $813(10)$ & $49.4(2.6) \mathrm{j}$ & $78.2(3.6) \mathrm{k}$ & $10.9(0.6) \mathrm{ab}$ & $2.04(0.09) \mathrm{a}$ & $0.04(0.005)$ af \\
\hline $\mathrm{J}$ & $808(20)$ & $16.3(0.8) \mathrm{f}$ & $42.8(2.5) \mathrm{f}$ & $15.2(1.0) \mathrm{fg}$ & $2.42(0.11) \mathrm{cd}$ & $0.09(0.008) \mathrm{c}$ \\
\hline $\mathrm{T}$ & $819(12)$ & $19.3(1.0) 1$ & $46.9(1.9) 1$ & $15.0(0.9) \mathrm{fg}$ & $2.39(0.12) b c$ & $0.08(0.007) b c$ \\
\hline $\mathrm{U}$ & $825(16)$ & $20.2(0.6) 1$ & $47.2(2.2) 1$ & $14.5(0.7)$ def & $2.31(0.11) b c$ & $0.06(0.007) \mathrm{ji}$ \\
\hline V & $818(21)$ & $20.6(0.9) 1$ & $48.8(1.5) 1$ & $14.4(0.9)$ def & $2.24(0.09) \mathrm{ab}$ & $0.05(0.004) \mathrm{fi}$ \\
\hline W & $814(14)$ & $23.9(0.7) \mathrm{e}$ & $52.8(1.8) \mathrm{m}$ & $13.6(0.6) \mathrm{cde}$ & $2.18(0.08) a b$ & $0.04(0.003)$ af \\
\hline
\end{tabular}

${ }^{1}$ See Table 1 for particleboard formulation; ${ }^{2}$ Groups with same letters in column indicate that there is no statistical difference ( $\mathrm{p}<0.01$ ) between the specimens according Duncan's multiply range test. The values in the parentheses are standard deviations.

content. Significant $(\mathrm{p}<0.01)$ differences were observed between the specimens with and without LDPE. The control specimens had much higher TS and WA values than the specimens containing the LDPE (Table 2). For example, the TS values of UF-bonded particeboards decreased from 102.9 to $58.6 \%$ as $5 \mathrm{wt} \%$ LDPE powder was incorporated into the core layer, and then decreased to $13.2 \%$ as the LDPE content increased up to $30 \mathrm{wt} \%$. Similar results were found for the PF-bonded particleboards. It is well known that the $\mathrm{PF}$ adhesives are resistant to wet conditions whereas UF adhesives are not. As the LDPE is a good barrier to water due to its hydrophobic character, by replacing UF by LDPE, swelling thickness and water absorption are significatively reduced. The positive effect of LDPE on the TS and WA of particleboards was not significant between 25 and $30 \mathrm{wt} \%$ LDPE contents (Table 2).

The UF-bonded particleboards swelled more than two times higher than the PF-bonded particleboards at all loading levels of LDPE (Table 2). Hydroxymethyl phenols will crosslink on heating to around $120^{\circ} \mathrm{C}$ to form methylene and methyl ether bridges through eliminating water molecules. At this point the PF adhesive is a 3-dimensional rigid network, which is typical of polymerised phenolic ${ }^{14}$. This makes the PF adhesive very resistant to water. However, the UF adhesive has lower water and weather resistance than the PF adhesive because aminomethylene linkages are susceptible to hydrolysis. Therefore, the UF adhesive is not stable at high humidity and temperature. Polycondensation of urea with formaldehyde usually results in hydrolytically sensitive bonds and low cross-link density which invariably increases sensitivity to losses in stress-bearing applications ${ }^{8}$.

The silica and waxy water repellent cuticle cover almost the entire outer layer of the rice husk ${ }^{15}$. The outer waxy layer of the rice husk particles has lower wettability. The silica in the husk is about $12 \%$ as ash content. The structure of silica was amorphous with a purity of $99.7 \% \mathrm{SiO}_{2}{ }^{[16]}$. The adhesive could not efficienty wet and penetrate to the cellular structure of rice husk due to its waxy cuticle. This results in the poor interfacial adhesion between the rice husk particles, which increases thickness swelling and water absorption of the particleboards.

As the amounts of UF and PF adhesives decreased from 8 to $4 \mathrm{wt} \%$ at the same LDPE content (10 wt $\%)$, the TS and WA vaules of the particeboards increased. However, the TS and WA values of the particleboard containing LDPE were significantly lower than the control specimens (Table 2). For example, the TS and WA values of particleboards bonded with $4 \mathrm{wt} \%$ UF adhesive and $10 \mathrm{wt} \%$ LDPE were $49.4 \%$ and $78.2 \%$ while they were found to be $102.9 \%$ and $95.5 \%$ for the control particleboards bonded with $10 \mathrm{wt} \% \mathrm{UF}$ adhesive, respectively. Similar results were observed for the PF-bonded particleboards. The decrease in the amount 
of UF adhesive or PF adhesive resulted in higher TS values because swelling induced stresses caused the separation of the rice husk particles within the core layer.

\subsection{Mechanical properties}

The incorporation of LDPE powder into the core layer of particleboard greatly improved the bonding between the rice husk particles. The IB values of particleboards increased by $366 \%$ and $280 \%$ as $30 \mathrm{wt} \%$ LDPE powder was incorporated into the core layer of UF- and PF-bonded particleboards, respectively. As compared to the control particleboards, the particeboards containing the LDPE powder, except for the particleboards containing $5 \mathrm{wt} \%$ LDPE, showed significant increases in the IB strength. Significant differences $(p<0.01)$ in the IB values are presented in Table 2 as letters. The increase in the amount of the LDPE powder considerably increased the IB strength because the LDPE powder led to better linkage between the rice husk particles. The polymer matrix used in the core layer acted as an adhesive to bond the rice husk particles together mechanically. The melted LDPE also improved the interfacial adhesion between core layer (rice husk particles) and face layers (wood particles) of the particleboard. Another explanation of this phenomenon was the uniform distribution of the melted LDPE over the rice husk particles. Similar results were found in previous studies regarding lignocelluosic filled thermoplastic composite panels ${ }^{17-19}$.

The IB strength of PF-bonded specimens was significantly higher than that of the UF-bonded specimens.
This revealed that the UF adhesive was more affected by the waxy silica layer compared with the PF adhesive. This is because the UF adhesive tends to have higher surface energy than the PF adhesive ${ }^{20}$. Although the IB strength of particleboards containing $10 \mathrm{wt} \%$ LDPE decreased with decreasing UF adhesive content in the core layer, it was higher than that of the control particleboards. For example, the average IB strength of the control particleboards was $0.03 \mathrm{~N} / \mathrm{mm}^{2}$ while it was found to be $0.04 \mathrm{~N} / \mathrm{mm}^{2}$ for the particleboards bonded with a mixture of $4 \mathrm{wt} \% \mathrm{UF}$ adhesive and $10 \mathrm{wt} \%$ LDPE. The IB strength values of control and particleboards made with a mixture of $4 \mathrm{wt} \%$ UF adhesive and $10 \mathrm{wt} \%$ LDPE were found to be $0.05 \mathrm{~N} / \mathrm{mm}^{2}$ and 0.04 $\mathrm{N} / \mathrm{mm}^{2}$, respectively. The IB strength of the particleboards containing $10 \mathrm{wt} \%$ LDPE powder decreased by $42.9 \%$ and $55.5 \%$ as the UF and PF adhesive contents decreased from 8 to $4 \%$, respectively.

Different fracture modes were observed during the IB tests. The fracture modes of particleboard samples with and without LDPE were presented in the Figure 2. The weakest area of fracture resistance was found in the core layer of the control samples. As shown in Figure 2, the fracture for the control samples without the LDPE was occured in the core layer while this was observed in the layer between the core layer and face layer of the samples with the LDPE. This result revealed the bonding between the rice husk particles was significantly improved by the melted LDPE. The fracture surfaces of IB test samples with and without LDPE were presented in Figure 2.

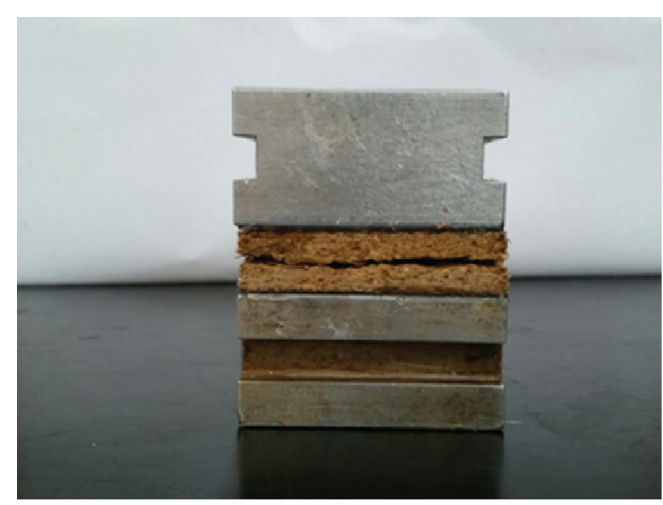

Control sample (without LDPE)

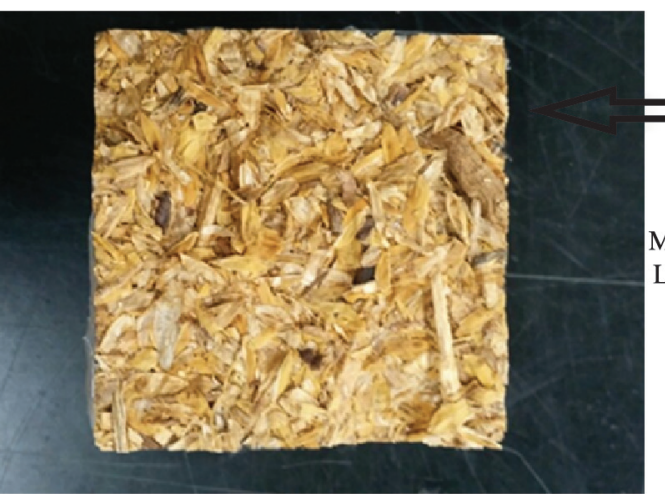

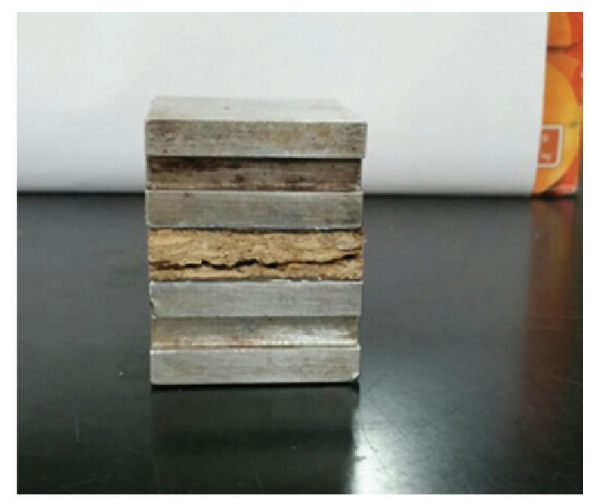

Control with LDPE in the core layer

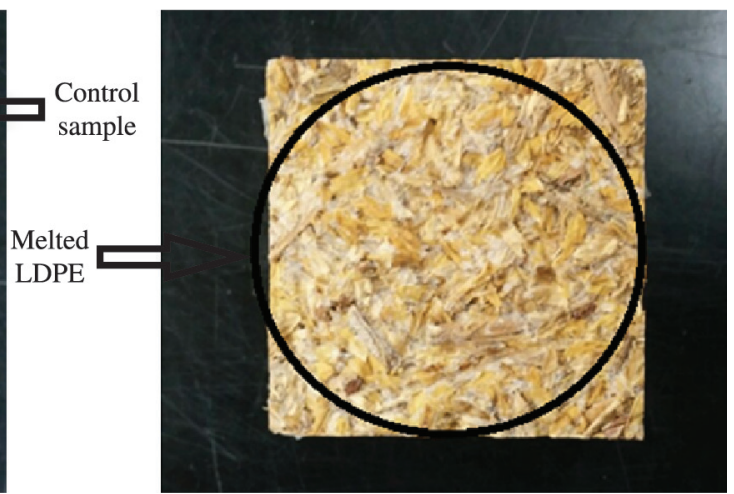

Figure 2. Fracture modes of the IB test samples with and without LDPE (top photos). The fracture surfaces of the IB test samples (below photos). 
The MOR and MOE of the particleboards were significantly improved by the incorporation of LDPE into the core layer (Table 2). The incorporation of the LDPE into the rice husk core layer increased the bonding performance between the rice husk particles. The LDPE decreased the micro voids in the core layer of particleboard, which resulted in increased strength and modulus. As $30 \mathrm{wt} \%$ LDPE was incorporated into the core layer, the MOR of the UF- and PF-bonded particleboards increased by $\mathbf{3 3 . 9 \%}$ and $27.9 \%$, respectively. The MOE of UF- and PF-bonded particleboards increased by $17.7 \%$ and $18.6 \%$ as $30 \mathrm{wt} \%$ LDPE was incorporated into the core layer, respectively. The MOR and MOE of the particleboards having rice husk core with LDPE were comparable with particleboards made from wood particles. For example, Nasser ${ }^{21}$ found that the MOR and MOE of three layer particleboards made from Pithecellobium dulce wood particles were $16.1 \mathrm{~N} / \mathrm{mm}^{2}$ and $2.56 \mathrm{GPa}$, respectively. In another study, Hiziroglu ${ }^{22}$ determined that MOR and MOE of UF-bonded particleboard were $11.7 \mathrm{~N} / \mathrm{mm}^{2}$ and $2.04 \mathrm{GPa}$, respectively.

The change in the values of MOR and MOE of the particleboards was associated with the characteristics of the outer layer and the core layer. This was because the outer layer was the layer subjected to higher stress levels when the sample was under flexion state. In the samples A to $\mathrm{G}$ (or $\mathrm{H}$ to $\mathrm{N}$ ) the amounts of thermoplastic adhesive increased in the core layer while the amount of rice husk decreased. Hence the total content of adhesive (thermosets and thermoplastics) increased. By increasing the content of adhesive, the value of MOE and MOR of boards improved slightly because only the core layer was modified.

The MOR and MOE of the particleboards containing $10 \mathrm{wt} \%$ LDPE decreased as the UF or PF adhesive content decreased from 8 to $4 \mathrm{wt} \%$ in the core layer (Table 2 ). This was due to the fact that the adhesives could effectively transfer and uniformly distribute stresses, thereby increasing the strength and stiffness of the particleboard. The MOR and MOE of particleboards containing $10 \mathrm{wt} \%$ the LDPE decreased with decreasing the amount of adhesive. However, there were no statistically significant differences in the MOR and MOE values of the particeboards as the UF

\section{References}

1. Kalia S, Kaith BS and Kaur I. Cellulose Fibers:Bio-and Nano-Polymer Composites: Green Chemistry and Technology. Dordrecht: Springer; 2001.

2. Luduena L, Fasce D, Alvarez VA and Stefani PM. Nanocellulose from rice husk following alkaline treatment to remove silica. BioResources. 2011; 6(2):1440-1453.

3. Johnson AC and Yunus NB. Particleboards from rice husk: a brief introduction to renewable materials of construction. Jurutera. 2009; 3:12-15.

4. Lee YK, Kim S, Yang HS and Kim HJ. Mechanical properties of rice husk flour-wood particleboards by urea-formaldehyde adhesive. Mokchae Konghak. 2003; 31:42-49.

5. Osarenmwinda JO and Nwachukwu JC. Effect of particle size on some properties of rice husk particleboard. Advanced Material Research. 2007; 18-19:43-48. http://dx.doi. org/10.4028/www.scientific.net/AMR.18-19.43. adhesive content decreased from 8 to $4 \mathrm{wt} \%$ in the core layer. The MOR of UF-bonded particleboards containing $10 \mathrm{wt} \%$ LDPE decreased from 12.1 to $10.9 \mathrm{~N} / \mathrm{mm}^{2}$ as the UF adhesive content decreased from 8 to $4 \mathrm{wt} \%$ in the core layer. As for the PF-bonded particeboards, the MOR decreased from 15.2 to $13.6 \mathrm{~N} / \mathrm{mm}^{2}$ as the $\mathrm{PF}$ adhesive content decreased from 8 to $4 \mathrm{wt} \%$ in the core layer. The IB, MOR, and MOE values of the PF-bonded particleboards were higher than those of the UF-bonded particleboards.

\section{Conclusions}

The dimensional stability and mechanical properties of particleboards with rice husk core were significantly improved by the incorporation of LDPE into thecore layer. As the amounts of UF and PF adhesives decreased from 8 to $4 \mathrm{wt} \%$ at the same LDPE content (10 wt $\%)$, the TS and WA of the particeboards increased, but were significantly lower than those of the control specimens. The reason was that a hydrophilic material $(\mathrm{RH})$ was replaced by a hydrophobic material (LDPE). Although the IB strength of particleboards containing $10 \mathrm{wt} \%$ LDPE decreased with decreasing UF adhesive content in the core layer, it was higher than that of the control particleboards. The MOR and MOE of the particleboards containing $10 \mathrm{wt} \%$ LDPE decreased with decreasing the amounts of UF and PF adhesives. However, there were no statistically significant differences in the MOR and MOE values of the particeboard types as the adhesive content decreased from 8 to $4 \mathrm{wt} \%$ in the core layer. Based on the findings obtained from the present study, it can be said that the rice husk particleboards containing LDPE, in particular above $20 \mathrm{wt} \%$ of LDPE, are suitable for use in damp places, such as bathrooms, toilets, kitchens, and laundries.

\section{Acknowledgements}

This study was supported by 2012 Research Grant from Kangwon National University and by the MSIP (Ministry of Science, Ict \& Future Planning). The authors would like to thank them for their financial support.
6. Garcia D, Lopez J, Balart R, Ruseckaite RA and Stefani PM. Composites based on sintering rice husk-waste tire rubber mixtures. Materials \& Design. 2007; 28(7):2234-2238. http:// dx.doi.org/10.1016/j.matdes.2006.06.001.

7. Wang HJ. Improving the adhesion of polyethylene by UV grafting. The Journal of Adhesion. 2006; 82(7):731-745. http:// dx.doi.org/10.1080/00218460600775815.

8. Atar I, Nemli G, Ayrilmis N, Baharoglu M, Sari B and Bardak S. Effects of hardener type, urea usage and conditioning period on the quality properties of particleboard. Materials \& Design. 2014; 56:91-96. http://dx.doi.org/10.1016/j. matdes.2013.10.078.

9. Rong X, Qiu F, Qin J, Yan J, Zhao H and Yang D. Removal of malachite green from the contaminated water using a water-soluble melamine/maleic anhydride sorbent. Journal of Industrial and Engineering Chemistry. 2014; 20(5):3808-3814. http://dx.doi.org/10.1016/j.jiec.2013.12.083. 
10. He Y, Zhang X, Zhang X, Huang H, Chang J and Chen H. Structural investigations of toluene diisocyanate (TDI) and trimethylolpropane (TMP)-based polyurethane prepolymer. Journal of Industrial and Engineering Chemistry. 2012; 18(5):1620-1627. http://dx.doi.org/10.1016/j.jiec.2012.02.023.

11. Nwanonenyi SC and Obidegwu MU. Analysis of mechanical properties of low density polyethylene/rice-husk composite using micro mathematical model equations. IOSR Journal of Engineering. 2012; 2(3):399-407. http://dx.doi. org/10.9790/3021-0203399407.

12. Ghofrani M, Pishan S, Mohammadi MR and Omidi H. A study on rice-husk/recycled high density polyethylene composites - their physical and mechanical properties. Environmental Sciences. 2012; 9:99-112.

13. Yao F, Wu Q, Lei Y and Xu Y. Rice straw fiber reinforced high density polyethylene composite: Effect of fiber type and loading. Industrial Crops and Products. 2008; 28(1):63-72. http://dx.doi.org/10.1016/j.indcrop.2008.01.007.

14. Allan GG and Neogi AN. The mechanism of adhesion of phenol-formaldehyde adhesives to cellulosic and lignocellulosic substrates. The Journal of Adhesion. 1971; 3(1):13-18. http:// dx.doi.org/10.1080/00218467108075002.

15. Torkaman J. Improvement of bondability in rice husk particleboard made with sodium silicate. In: Proceedings of the 2nd International Conference on Sustainable Construction Materials and Technologies; 2010; Ancona, Italy. Ancona, Italy: Universita Politecnica dele Marche; 2010. p. 125-133.
16. Park BD, Wi SG, Lee KH, Singh AP, Yoon TH and Kim YS. Characterization of anatomical features and silica distribution in rice husk using microscopic and micro-analytical techniques. Biomass and Bioenergy. 2003; 25(3):319-327. http://dx.doi. org/10.1016/S0961-9534(03)00014-X.

17. Ayrilmis $\mathrm{N}$ and Jarusombuti S. Flat-pressed wood plastic composite as an alternative to conventional wood-based panels. Journal of Composite Materials. 2011; 45(1):103-112. http:// dx.doi.org/10.1177/0021998310371546.

18. Ayrilmis N, Jarusombuti S, Fueangvivat V, Bauchongkol P and White $\mathrm{RH}$. Coir fiber reinforced polypropylene composite panel for automotive interior applications. Fibers and Polymers. 2011; 12(7):919-926. http://dx.doi.org/10.1007/s12221-0110919-1.

19. Rosa SML, Santos EF, Ferreira CA and Nachtigall SMB. Studies on the properties of rice-husk-filled-PP composites - effect of maleated PP. Materials Research. 2009; 12(3):333338. http://dx.doi.org/10.1590/S1516-14392009000300014.

20. Pizzi A and Mittal KL. Handbook of Adhesive Technology. 2nd ed. New York: Marcel Dekker; 2003. Revised and Expanded.

21. Nasser RAS. Physical and mechanical properties of three-layer particleboard manufactured from the tree pruning of seven wood species. World Applied Science Journal. 2012; 19:741753.

22. Hiziroglu S. Some of the properties of three-layer particleboard panels made from under-utilized species in Oklahoma. Journal of Composite Materials. 2007; 41(4):467-476. http://dx.doi. org/10.1177/0021998306063805. 